\title{
HUBUNGAN PERSEPSI TERHADAP PERINGATAN BAHAYA MEROKOK PADA KEMASAN ROKOK DENGAN PERILAKU MEROKOK PADA REMAJA LAKI-LAKI DI KOTA PALEMBANG
}

\author{
Afria Tantri, Nur Alam Fajar, Feranita Utama \\ Fakultas Kesehatan Masyarakat Universitas Sriwijaya
RELATIONSHIP PERCEPTION MALE TEENAGERS OF THE DANGERS SMOKING AND WARNING ON THE CIGARETTE PACKAGES OF MALE TEENAGERS AND \\ BEHAVIOR SMOKING IN PALEMBANG
}

\begin{abstract}
Background: Inclusion of the dangers smoking and warning on the cigarette packages generate multiple views in society, especially among teenagers, because teenagers are easily affected by something new, unique, and interesting. The aim of study to know the perception of the dangers smoking and warning on the cigarette packages of male teenagers about behavior smoking in Palembang.

Method: The method of this study is quantitative with cross sectional study. The population of this study is male teenagers in Palembang are selected as the samples by using multistage random sampling. The data collection was done through interview method by using questionnaire. The data analysis technique with multiple logistic regression test.

Result: Statistics test showed that the variables associated with the smoking behavior was perceived susceptibility, perceived severity, perceived benefits, perceived barriers, and cues to actio), while the variable that was not associated with the smoking behavior is variable self efficacy $(p=0,734)$. The result multivariate analysis showed that the variable that most influence on smoking behavior was length of perceived susceptibility.

Conclusion: The study concluded perceived susceptibility, perceived benefits, and perceived barriers are risks factors for male teenagers about behavior smoking in Palembang. Attention from the family is needed to reduce smoking behavior, especially among teenagers.
\end{abstract}

Keywords: Perception, smoking behavior, cigarette packages

\begin{abstract}
ABSTRAK
Latar Belakang: Pencantuman iklan peringatan bahaya merokok di kemasan rokok menimbulkan berbagai macam pandangan di kalangan masyarakat terutama di kalangan remaja, karena remaja mudah terpengaruh terhadap sesuatu yang baru, unik, dan menarik. Penelitian ini bertujuan untuk melihat persepsi terhadap peringatan bahaya merokok pada kemasan rokok dan hubunganya dengan perilaku merokok remaja laki-laki di Kota Palembang.

Metode: Penelitian ini menggunakan metode kuantitatif dengan desain cross sectional. Populasi penelitian adalah remaja laki-laki di Kota Palembang dengan sampel 125 responden yang dipilih menggunakan multistage random sampling. Pengumpulan data dilakukan dengan metode wawancara menggunakan kuesioner. Teknik analisis data dilakukan dengan uji regresi logistik ganda.

Hasil Penelitian: Statistik menunjukkan bahwa variabel yang berhubungan dengan perilaku merokok adalah persepsi kerentanan, persepsi keseriusan, persespi manfaat, persepsi hambatan, dan isyarat untuk bertindak, sementara variabel yang tidak berhubungan dengan perilaku merokok adalah variabel efikasi diri. Hasil analisis multivariat didapatkan bahwa variabel yang paling berpengaruh terhadap perilaku merokok adalah persepsi kerentanan.

Kesimpulan: Penelitian ini menyimpulkan persepsi keseriusan, persepsi manfaat, dan persepsi hambatan merupakan risiko penyebab perilaku merokok remaja laki-laki di Kota Palembang. Perhatian dari keluarga sangat di perlukan untuk mengurangi perilaku merokok terutama di kalangan remaja.
\end{abstract}

Kata Kunci: Persepsi, perilaku merokok, kemasan rokok

Alamat Koresponding: Afria Tantri, Fakultas Kesehatan Masyarakat Universitas Sriwijaya. Jl. Palembang Prabumulih KM. 32, Indralaya Indah Kabupaten Ogan Ilir, Sumatera Selatan, email : ms.afriatantri18@gmail.com 


\section{PENDAHULUAN}

Perilaku merokok membahayakan diri sendiri maupun orang lain yang berada disekitarnya, karena asap rokok mengandung lebih dari 4000 zat kimia berbahaya serta lebih dari 43 zat penyebab kanker. ${ }^{1}$ Berdasarkan persentase negara dengan produsen tembakau terbesar di dunia, Indonesia berada di posisi keenam dengan jumlah produksi tembakau sebesar 136 ribu ton atau sekitar $1,91 \%$ dari total produksi tembakau dunia. $^{2}$

Peningkatan perilaku merokok berdampak pada semakin tingginya beban penyakit akibat rokok dan bertambahnya angka kematian, diperkirakan angka kematian akibat rokok mencapai $70 \%$ pada tahun 2030 dan setengahnya berdampak pada penduduk berusia produktif. ${ }^{3}$ Prevalensi merokok di Indonesia umur $>15$ tahun berdasarkan hasil Riskesdas tahun 2007 sebesar 34,2\%, pada tahun 2010 sebesar 34,7\% dan tahun 2013 sebesar $36,3 \% .^{4}$ Prevalensi merokok sangat tinggi pada kalangan remaja terutama pada remaja laki-laki. Berdasarkan hasil Riskesdas tahun 2007, 2010, dan 2013 persentase perokok laki-laki sebesar $55,7 \%, 65,9 \%$, dan $56,7 \%$ sedangkan perokok perempuan sebesar $4,4 \%, 4,3 \%$, dan $1,9 \% .^{5,6,7}$

Di Provinsi Sumatera Selatan, prevalensi perilaku merokok berdasarkan jumlah persentase umur $>10$ tahun ke atas (terdiri dari perokok setiap hari dan perokok kadang-kadang) sebesar $31,7 \%$, 36,5\%, dan $30,1 \%{ }^{5,6,7}$ Di Kota Palembang prevalensi perokok setiap tahunya terus mengalami peningkatan, berdasarkan hasil survey Badan Pusat Statistik dan Dinas Kesehatan Kota Palembang pada tahun 2012, 2013, dan 2014 prevalensi perokok sebesar $34,17 \%, 43,17 \%$, dan $58,17 \% .{ }^{8} \mathrm{Hal}$ ini menunjukkan bahwa di Kota Palembang prevalensi merokok setiap tahunnya terus mengalami peningkatan.

Asap rokok yang dihasilkan dari rokok dapat menyebabkan berbagai penyakit yang sangat membahayakan seperti kanker paru- paru, asma, penyakit jantung iskemik, kanker saluran pernafasan, kanker tenggorokan, insomnia, impoten, dan sebagainya. ${ }^{9}$ Paparan asap rokok menewaskan lebih dari 600.000 non-perokok pada tahun $2010 .{ }^{2}$ Melihat besarnya risiko perilaku merokok, pemerintah Indonesia berupaya untuk menekan semakin tingginya angka prevalensi merokok pada usia muda, dengan mengeluarkan aturan mengenai Pengamanan Bahan yang Mengandung Zat Adiktif Berupa Produk Tembakau Bagi Kesehatan. Salah satu isinya adalah seluruh rokok yang beredar di Indonesia harus menyertakan peringatan bahaya rokok, disertai gambar menyeramkan akibat merokok pada bungkus rokok. ${ }^{1}$

Berdasarkan permasalahan tersebut, penelitian ini bertujuan untuk mengetahui hubungan persepsi remaja laki-laki terhadap peringatan bahaya merokok pada kemasan rokok dan perilaku merokok remaja laki-laki di Kota Palembang.

\section{METODE}

Penelitian ini menggunakan desain penelitian cross sectional. Populasi dalam penelitian ini remaja laki-laki yang berada di Kota Palembang. Sebanyak 125 responden usia 10-19 tahun menjadi sampel dalam penelitian ini. pengambilan sampel dengan menggunakan teknik multistagerandom sampling. Pengumpulan data penelitian menggunakan kuesioner. Variabel dependen dalam penelitian adalah perilaku merokok, sedangkan variabel independen yaitu persepsi kerentanan, persepsi keseriusan, persepsi manfaat, persepsi hambatan, efikasi diri, dan isyarat untuk bertindak. Analisis data yang digunakan yaitu analisis univariat, analisis bivariat dengan menggunakan chi square, dan analisis multivariate dengan menggunakan regresi linier ganda.

\section{HASIL PENELITIAN}

Analisis univariat persepsi remaja lakilaki terhadap iklan peringatan bahaya 
merokok pada kemasan rokok dan perilaku dapat dilihat pada Tabel 1.

merokok remaja laki-laki di Kota Palembang

Tabel 1.

Persepsi Remaja Laki-Laki terhadap Peringatan Bahaya dan Perilaku Merokok Remaja Laki-Laki di Kota Palembang

\begin{tabular}{lcc}
\hline \multicolumn{1}{c}{ Variabel } & N & f(\%) \\
\hline Perilaku Merokok & & \\
Merokok & 82 & 65,6 \\
Tidak Merokok & 43 & 34,4 \\
Persepsi Kerentanan & 71 & 56,8 \\
Rendah & 54 & 43,2 \\
Tinggi & & 54,4 \\
Persepsi Keseriusan & 68 & 45,6 \\
Rendah & 57 & 60,0 \\
Tinggi & & 40,0 \\
Persepsi Manfaat & 75 & 44,8 \\
Rendah & 50 & 55,2 \\
Tinggi & & 72,8 \\
Persepsi Hambatan & 56 & 27,2 \\
Rendah & 69 & 52,8 \\
Tinggi & & 47,2 \\
Efikasi Diri & 91 & \\
Rendah & 34 & \\
Tinggi & & \\
Isyarat Untuk Bertindak & 66 & \\
Rendah & 59 & \\
Tinggi & & \\
\hline
\end{tabular}

Berdasarkan Tabel 1 sebagian besar remaja laki-laki merokok $(65,6 \%)$. Persepsi remaja laki-laki yang merokok dan tidak merokok terhadap iklan peringatan bahaya merokok pada kemasan rokok sangat beragam, bisa dilihat dari persepsi kerentanan yang dirasakan remaja laki-laki. Remaja lakilaki dengan persepsi kerentanan cukup rendah $(56,8 \%)$. Persepsi keseriusan yang dirasakan remaja laki-laki untuk menderita penyakit akibat dari merokok cukup rendah $(54,4 \%)$.

Persepsi manfaat yang dirasakan remaja laki-laki setelah dicantumkan iklan peringatan bahaya merokok belum dirasakan manfaatnya oleh responden, dapat dilihat persepsi manfaatnya masih rendah $(60,0 \%)$. Persepsi hambatan yang dirasakan remaja laki-laki jug cukup tinggi $(55,2 \%)$. Efikasi diri di dalam diri remaja laki-laki terhadap iklan peringatan bahaya merokok pada kemasan rokok juga masih cukup rendah $(72,8 \%)$. Isyarat untuk bertindak yang dirasakan respon juga masih cukup rendah $(52,8 \%)$.

Analisis bivariat hubungan persepsi remaja laki-laki terhadap iklan peringatan bahaya merokok pada kemasan rokok dan perilaku merokok remaja laki-laki di Kota Palembang dapat dilihat pada Tabel 2 di bawah ini.

Tabel 2.

Hubungan Persepsi terhadap Peringatan Bahaya Merokok pada Kemasan Rokok dengan Perilaku Merokok pada Remaja Laki-Laki di Kota Palembang

\begin{tabular}{|c|c|c|c|c|c|c|}
\hline \multirow{3}{*}{ Variabel } & \multicolumn{4}{|c|}{ Perilaku Merokok } & \multirow{3}{*}{ p-value } & \multirow{3}{*}{$\begin{array}{c}\text { PR } \\
(95 \% \mathrm{CI})\end{array}$} \\
\hline & \multicolumn{2}{|c|}{ Merokok } & \multicolumn{2}{|c|}{ Tidak Merokok } & & \\
\hline & n & $\%$ & $\mathbf{n}$ & $\%$ & & \\
\hline Persepsi Kerentanan & & & & & 0,000 & 43,5 \\
\hline Rendah & 67 & 81,7 & 4 & 9,3 & & $(13,497-140,521)$ \\
\hline
\end{tabular}




\begin{tabular}{|c|c|c|c|c|c|c|}
\hline Tinggi & 15 & 18,3 & 39 & 90,7 & & \\
\hline Persepsi Keseriusan & & & & & 0,000 & 5,5 \\
\hline Rendah & 56 & 68,3 & 12 & 27,9 & & $(2,469-12,541)$ \\
\hline Tinggi & 26 & 31,7 & 31 & 72,1 & & \\
\hline Persepsi Manfaat & & & & & 0,001 & 3,6 \\
\hline Rendah & 58 & 70,7 & 17 & 39,5 & & $(1,703-8,019)$ \\
\hline Tinggi & 24 & 29,3 & 26 & 60,5 & & \\
\hline Persepsi Hambatan & & & & & 0,000 & 9,6 \\
\hline Rendah & 50 & 61,0 & 6 & 14,0 & & $(3,653-15,418)$ \\
\hline Tinggi & 32 & 39,0 & 37 & 86,0 & & \\
\hline Efikasi Diri & & & & & 0,734 & 1,2 \\
\hline Rendah & 61 & 74,4 & 30 & 69,8 & & $(0,555-2,853)$ \\
\hline Tinggi & 21 & 25,6 & 13 & 30,2 & & \\
\hline Isyarat Untuk Bertindak & & & & & 0,050 & 2,2 \\
\hline Rendah & 49 & 59,8 & 17 & 39,5 & & $(1,068-4,827)$ \\
\hline Tinggi & 33 & 40,2 & 26 & 60,5 & & \\
\hline
\end{tabular}

Analisis multivariat yang menunjukkan hubungan persepsi remaja laki-laki terhadap iklan peringatan bahaya merokok pada kemasan rokok dan perilaku merokok remaja laki-laki di Kota Palembang dapat dilihat pada Tabel 3 di bawah ini.

Tabel 3.

Hubungan Persepsi terhadap Peringatan Bahaya Merokok pada Kemasan Rokok dengan Perilaku Merokok pada Remaja Laki-Laki di Kota Palembang

\begin{tabular}{lcc}
\hline \multicolumn{1}{c}{ Variabel } & \multicolumn{2}{c}{ Model } \\
\cline { 2 - 3 } & p-value & $\begin{array}{c}\mathbf{E x p}(\mathbf{B}) \\
\mathbf{( 9 5 \%} \mathbf{C I})\end{array}$ \\
\hline $\begin{array}{l}\text { Persepsi } \\
\text { Kerentanan }\end{array}$ & 0,000 & $\begin{array}{c}25,421(7,402- \\
87,304)\end{array}$ \\
$\begin{array}{l}\text { Persepsi } \\
\text { Keseriusan } \\
\text { Persepsi }\end{array}$ & 0,128 & $2,460(0,771-7,848)$ \\
manfaat & 0,507 & $1,486(0,461-4,787)$ \\
$\begin{array}{l}\text { Persepsi } \\
\text { hambatan }\end{array}$ & 0,011 & $4,958(1,454-16,905)$ \\
\hline
\end{tabular}

Faktor yang berhubungan signifikan secara statistik yang mempengaruhi perilaku merokok remaja laki-laki yaitu persepsi kerentanan dan persepsi hambatan setelah dikontrol oleh variabel lain (Tabel 3). Variabel yang paling dominan dalam penelitian ini adalah variabel persepsi kerentanan.

\section{PEMBAHASAN}

Persepsi Kerentanan yang Dirasakan Setelah Melihat dan Membaca Peringatan Bahaya Merokok pada Kemasan Rokok

Hasil penelitian menunjukkan bahwa ada hubungan antara persepsi kerentanan dengan perilaku merokok remaja laki-laki di Kota Palembang ( $p$-value $<0,000)$. Remaja laki-laki merasa diri mereka tidak rentan untuk menderita penyakit seperti yang tertera pada kemasan rokok meskipun telah merokok dalam jangka waktu yang lama sebesar $56,8 \%$. Penelitian ini sejalan dengan penelitian sebelumnya yang menunjukkan bahwa persepsi kerentanan yang dirasakan terhadap iklan peringatan bahaya merokok pada kemasan rokok belum mewakili bahaya yang dapat ditimbulkan akibat dari perilaku merokok. $^{10}$

Kerentanan yang dirasakan remaja terhadap perilaku merokok biasanya dipengaruhi oleh pandangan mengenai penyakit yang ditimbulkan secara umum bukan karena akibat rokok. Para perokok remaja tidak merasa dirinya termasuk ke dalam kelompok rentan karena dampak fisik akibat dari rokok tidak akan dirasakan dalam waktu yang singkat. Hasil analisis dari kuesioner diketahui gambar yang tertera pada kemasan rokok membuat perokok aktif dan pasif tidak akan mengalami gangguan 
kesehatan seperti yang tertera pada kemasan rokok.

Analisis lebih lanjut pada analisis multivariat menunjukkan persepsi kerentanan merupakan variabel yang paling dominan terhadap perilaku merokok, karena persepsi kerentanan langsung mengacu kepada penilaian subjektif terhadap risiko dari masalah kesehatan dan termasuk salah satu faktor yang mempengaruhi perilaku merokok seseorang yang bisa dilihat dari intensitas merokoknya. ${ }^{11,12}$ Selain perilaku merokok dan intensitas merokok, tingginya persepsi kerentanan dapat juga disebabkan karena adanya pengetahuan, dari pengetahuan yang mereka miliki mengenai iklan peringatan tersebut membuat responden meresponnya ke dalam suatu tindakan. ${ }^{13}$ Tingginya persepsi kerentanan yang dirasakan tersebut dapat juga timbul karena adanya sikap yang sebelumnya sudah dimiliki oleh responden. ${ }^{14}$

\section{Persepsi Keseriusan yang Dirasakan Setelah Melihat dan Membaca Peringatan Bahaya Merokok pada Kemasan Rokok}

Rendahnya persepsi keseriusan yang dirasakan membuat mereka sulit untuk mengambil suatu tindakan dalam mengatasi masalah yang akan muncul. ${ }^{15}$ Analisis lebih lanjut dari kuesioner dapat dilihat bahwa remaja laki-laki merasa jika merokok dalam jangka waktu yang lama tidak akan menyebabkan responden menderita penyakit kanker seperti yang terdapat pada kemasan rokok dan remaja laki-laki tidak percaya jika penyakit kanker akibat dari perilaku merokok karena bisa saja penyakit kanker disebabkan dari faktor lain. Hasil analisis kuesioner ini sesuai dengan teori yang menyebutkan semakin tinggi persepsi keseriusan maka semakin besar persepsi masalah terhadap suatu ancaman sehingga semakin besar kemungkinan untuk mengambil suatu tindakan dalam mengatasi masalah yang akan muncul dan sebaliknya. ${ }^{15}$
Hal ini sejalan dengan penelitian sebelumnya yang menyatakan persepsi keseriusan terhadap peringatan kesehatan bergambar dan peringatan teks saja dapat mempengaruhi perilaku merokok seseorang dan penelitian lain juga menyatakan persepsi keseriusan yang dirasakan mahasiswa terhadap lima tipe gambar peringatan bahaya merokok pada kemasan rokok membuat mahasiswa berhenti merokok. ${ }^{10,16} \mathrm{Pada}$ penelitian ini terdapat pengaruh eksternal yaitu berupa pesan, anjuran atau nasihat orang tua yang mempengaruhi persepsi keseriusan. Jika faktor eksternal tersebut dapat mempengaruhi persepsi keseriusan yang dirasakan responden, maka akan besar kemungkinan persepsi keseriusan yang dirasakan mempengaruhi seseorang untuk berperilaku. $^{17}$

\section{Persepsi Manfaat yang Dirasakan Setelah Melihat dan Membaca Peringatan Bahaya Merokok pada Kemasan Rokok}

Hasil penelitian menunjukkan ada hubungan antara persepsi manfaat dengan perilaku merokok remaja laki-laki di Kota Palembang. Remaja laki-laki tidak merasakan adanya manfaat yang didapatkan setelah melihat dan membaca iklan bahaya merokok pada kemasan rokok sehingga mereka merokok sebesar $60,0 \%$.

Berdasarkan analisis di lapangan, remaja laki-laki tidak merasakan manfaat dari aturan pemerintan mengenai pencantuman gambar berbagai penyakit yang ada di kemasan rokok, mereka merasa pengetahuan mereka tidak bertambah setelah melihat dan membaca iklan tersebut karena mereka sudah mengetahuinya terlebih dahulu dan remaja laki-laki akan tetap saja merokok karena merasa sudah ketagihan sehingga sulit untuk menjauhi rokok. Sesuai degan sebuah teori yang menyatakan persepsi yang dirasakan responden menyebabkan adanya perubahan perilaku yang dipengaruhi oleh keyakinan mengenai manfaat yang dirasakan untuk 
mengurangi ancaman penyakit, manfaat yang dirasakan merujuk individu untuk beperilaku mengurangi risiko penyakit dan manfaat yang dirasakan juga merujuk kepada penilaian individu dalam berperilaku untuk mengurangi risiko. $^{11}$

Sejalan dengan penelitian sebelumnya yang menyatakan terdapat hubungan antara persepsi manfaat yang dirasakan dari tindakan pencegahan pada pasien yang merokok di Puskesmas Ciputat Tanggerang Selatan dan peneliti lain yang juga menyatakan terdapat hubungan antara persepsi manfaat yang dirasakan dari tindakan perilaku pencegahan hipertensi akibat rokok. ${ }^{18,19}$ Remaja laki-laki dengan persepsi manfaat rendah, remaja lakilaki merasa sudah menderita penyakit sebelum mereka merokok sehingga mereka tidak memperdulikan iklan peringatan pada kemasan rokok tersebut. Seseorang cenderung akan menerapkan suatu perilaku yang sehat ketika ia merasakan perilaku tersebut dapat berdampak positif bagi kesehatannya begitupun sebaliknya. ${ }^{17}$

\section{Persepsi Hambatan yang Dirasakan setelah Melihat dan Membaca Peringatan Bahaya Merokok pada Kemasan Rokok}

Hasil penelitian dengan uji statistik menunjukkan adanya hubungan antara persepsi hambatan dengan perilaku merokok remaja laki-laki di Kota Palembang. Remaja laki-laki merasakan tidak adanya hambatan yang dirasakan untuk merokok setelah melihat dan membaca iklan peringatan bahaya merokok pada kemasan rokok sebesar 55,2\%. Pada penelitian ini remaja laki-laki dengan persepsi hambatan yang rendah, remaja lakilaki tidak merasakan adanya rintangan atau penghalang untuk mereka merokok meskipun telah melihat dan membaca iklan bahaya merokok pada kemasan rokok.

Analisis lebih lanjut dari hasil pengamatan di lapangan, remaja laki-laki beranggapan gambar berbagai penyakit yang ada di kemasan rokok bertujuan untuk menakut-nakuti para perokok aktif agar mereka berhenti merokok dan remaja laki-laki tidak memperdulikan setiap gambar penyakit yang ada di kemasan rokok karena mereka tidak mempercayai akan gambar tersebut. Hambatan yang dirasakan ini termasuk suatu konsekuensi negatif yang timbul ketika mengambil suatu tindakan tertentu termasuk tuntutan fisik, psikologis, dan keuangan. ${ }^{20}$

Sejalan dengan penelitian sebelumnya yang menyatakan adanya hubungan antara persepsi hambatan yang dirasakan responden dalam upaya berhenti merokok terhadap tipe perilaku merokok. ${ }^{21}$ Persepsi hambatan merupakan pandangan atau penilaian individu mengenai ada atau tidak ada hambatan yang dirasakan setelah melihat dan membaca iklan peringatan bahaya merokok tersebut. ${ }^{18}$

\section{Efikasi Diri Remaja Laki-Laki Setelah Melihat dan Membaca Peringatan Bahaya Merokok pada Kemasan Rokok}

Berdasarkan hasil penelitian tidak ada hubungan antara efikasi diri dengan perilaku merokok remaja laki-laki di Kota Palembang. Hasil analisis kuesioner remaja laki-laki meyakini anak-anak yang terpapar asap rokok akan berbahaya bagi kesehatan mereka dan penyakit akibat rokok yang tertera di kemasan rokok akan di derita oleh responden yang belum merokok dalam jangka waktu yang lama. Efikasi diri mempengaruhi seberapa besar usaha seseorang saat akan mencoba sesuatu hal yang baru dalam mengatasi masalah yang muncul. ${ }^{22}$

Penelitian ini sama seperti penelitian sebelumnya yang menunjukkan tidak terdapat hubungan yang signifikan antara keyakinan terhadap kemampuan diri untuk berhenti merokok. ${ }^{23}$ Pada penelitian ini kemampuan diri remaja laki-laki tinggi, remaja laki-laki memiliki keyakinan yang kuat untuk tidak merokok karena sudah jelas jika merokok berbahaya bagi kesehatan. Efikasi diri berupa keyakinan seseorang dapat berhasil 
mengeksekusi perilaku yang diperlukan untuk menghasilkan suatu tindakan. ${ }^{18}$

Semakin tinggi efikasi diri maka semakin tinggi perilaku sehat, jika perilaku sehat subjek tinggi artinya subjek tidak melakukan perilaku berisiko terhadap kesehatan. ${ }^{22}$ Remaja laki-laki merasa memiliki kemampuan diri yang baik dalam menanggapi gambar bahaya merokok yang ada pada kemasan rokok sehingga membuat remaja laki-laki tidak merokok. Hal ini disebabkan oleh berbagai aspek, perilaku tersebut dipengaruhi oleh tiga komponen yaitu sikap, norma subjektif, persepsi kontrol perilaku. ${ }^{24}$

Niat berperilaku dalam penelitian ini meliputi sikap responden setelah melihat dan membaca iklan bahaya merokok pada kemasan rokok, responden masih ragu terhadap dampak yang akan terjadi jika merokok dapat dilihat dari kuesioner dimana responden ragu tidak akan terkena dampak penyakit akibat merokok karena baru merokok. Norma subjektif berupa hak pribadi responden untuk menentukan apa yang akan dilakukan, dimana responden akan mengabaikan pandangan orang tentang perilaku yang akan dilakukannya, dalam hal ini responden memiliki kepercayaan yang tinggi sehingga memutuskan untuk tidak merokok. Persepsi kontrol perilaku berupa pernah melaksanakan atau tidak pernah melaksanakan perilaku tertentu, dalam hal ini responden memiliki kemampuan untuk tidak merokok karena responden merasa biasa saja setelah melihat dan membaca iklan bahaya merokok pada kemasan rokok.

\section{Isyarat Untuk Bertindak Setelah Melihat dan Membaca Peringatan Bahaya Merokok pada Kemasan Rokok}

Hasil penelitian menunjukkan ada hubungan antara isyarat untuk bertindak dengan perilaku merokok remaja laki-laki di Kota Palembang. Remaja laki-laki akan melakukan suatu tindakan setelah melihat dan membaca iklan bahaya merokok pada kemasan rokok sebesar 52,8\%. Isyarat untuk bertindak berpengaruh terhadap ancaman penyakit, sehingga responden yang menyatakan besarnya ancaman yang dirasakan mempengaruhi dorongan untuk melakukan sesuatu, berupa strategi untuk meningkatkan kesadaran, strategi untuk mengaktifkan kesiapan, dan sebagai sistem pengingat yang tepat. ${ }^{20}$

Teori ini sesuai dengan fakta di lapangan, dapat dilihat dari analisis kuesioner responden tidak takut untuk merokok meskipun telah dipasang gambar penyakit pada kemasan rokok, dan responden tidak akan berhenti merokok walaupun pemerintah telah mencantumkan penyakit akibat merokok pada kemasan rokok. Isyarat untuk bertindak berupa sumber darimana individu mendapatkan informasi mengenai masalah kesehatan yang terjadi. ${ }^{25}$ Informasi berupa media iklan pada kemasan rokok sebagai faktor yang mempengaruhi persepsi. Media yang dapat mempengaruhi persepsi ancaman responden yang kemudian memiliki niatan untuk mengubah perilaku adalah media yang mempunyai tingkat kejelasan, keseraman, dan informatif yang baik. ${ }^{10}$

Sejalan dengan penelitian sebelumnya yang menyatakan adanya pengaruh positif peringatan kesehatan bergambar pada kemasan rokok terhadap motivasi perokok untuk berhenti merokok dan penelitian lain yang juga menyatakan mahasiswa berniat untuk mengurangi konsumsi rokok setelah melihat gambar peringatan yang ada di kemasan rokok. ${ }^{10,26}$ Isyarat untuk bertindak dapat dipengaruhi dari isyarat internal dan eksternal. ${ }^{15}$ Isyarat internal mencakup isyarat untuk bertindak yang berasal dari dalam diri individu. Isyarat eksternal mencakup tindakan dan informasi dari orang lain, dalam hal ini iklan bahaya merokok yang terdapat di kemasan rokok dinilai efektif karena langsung menunjukkan bahaya yang dapat ditimbulkan akibat dari perilaku merokok, tetapi komposisi iklan bergambar merokok masih belum mampu membuat responden untuk tidak 
merokok. ${ }^{27}$ Pada penelitian ini responden belum merasakan adanya dorongan motivasi dari dalam dirinya untuk tidak merokok atau mengurangi jumlah konsumsi rokoknya setelah melihat dan membaca iklan peringatan bahaya merokok yang ada pada kemasan rokok.

\section{KESIMPULAN DAN SARAN}

Kesimpulan dari penelitian ini adalah sebagai berikut:

1. Terdapat $65,6 \%$ remaja laki-laki yang merokok. Ada berbagai alasan yang membuat mereka merokok antara lain ingin mengetahui rasanya, dipengaruhi oleh teman, dan untuk menghilangkan rasa stress.

2. Ada hubungan antara persepsi kerentanan, keseriusan, manfaat, hambatan dan isyarat untuk bertindak $(0,050)$ dengan perilaku merokok di Kota Palembang.

3. Tidak ada hubungan antara efikasi diri dengan perilaku merokok remaja laki-laki di Kota Palembang.

4. Faktor yang berhubungan signifikan secara statistik dengan perilaku merokok remaja

\section{DAFTAR PUSTAKA}

1. Peraturan Pemerintah Republik Indonesia. Pengamanan Bahan yang Mengandung Zat Adiktif Berupa Produk Tembakau Bagi Kesehatan UndangUndang Nomor 109 Tahun 2012. Pemerintah Republik Indonesia. Jakarta. 2012.

2. Eriksen, M., Mackay, J., dan Ross, H. The Tobacco Atlas, $5^{\text {th }}$ ed., 31, the American Cancer Society. Inc, USA. 2015.

3. Kementrian Kesehatan Republik Indonesia. Pusat Data dan Informasi Kementrian Kesehatan RI Perilaku Merokok Masyarakat Indonesia. Infodatin, Jakarta. 2014.

4. WHO, Regional Office for South-East Asia. WHO-SEARO, New Delhi. 2014.

5. Kemenkes Republik Indonesia. Hasil Riset Kesehatan Dasar (Riskesdas) laki-laki yaitu persepsi kerentanan dan persepsi hambatan setelah dikontrol oleh variabel lain. Variabel yang paling dominan dalam penelitian ini adalah variabel persepsi kerentanan. Remaja lakilaki yang memiliki persepsi kerentanan yang rendah berpeluang 25 kali lebih besar untuk berperilaku merokok di Kota Palembang.

Saran dari penelitian ini adalah sebagai berikut:

a. Bagi Pemerintah Kota Palembang, sebaiknya peraturan Kawasan Tanpa Rokok (KTR) harus benar-benar ditindak tegas sesuai dengan sanksi yang telah ditetapkan, karena untuk saat ini Peraturan Kawasan Tanpa Rokok tersebut belum diterapkan sebagaimana mestinya.

b. Bagi penelitian selanjutnya, sebaiknya peneliti lain dapat melakukan penelitian variabel yang dapat menggambarkan perilaku merokok remaja laki-laki terhadap respon iklan penyakit pada kemasan rokok, seperti usia, pendidikan, pengetahuan, dan pengaruh lingkungan.

Tahun 2007. Badan Litbangkes, Depkes RI , Jakarta. 2007.

6. . Hasil Riset Kesehatan Dasar (Riskesdas) Tahun 2010. Badan Litbangkes, Depkes RI , Jakarta. 2010.

7. Hasil Riset Kesehatan Dasar

(Riskesdas) Tahun 2013. Badan Litbangkes, Depkes RI , Jakarta. 2013.

8. Pusat Data dan Informasi

Kementrian Kesehatan RI Perilaku Merokok Masyarakat Indonesia. Infodatin, Jakarta. 2014.

9. Stalker, P. Kita Suarakan MDGs Demi Pencapaiannya di Indonesia, Laporan MDGs. UI Update, Jakarta. 2008.

10. Lakhmudien. Persepsi Mahasiswa UDINUS Terhadap Lima Tipe Gambar Peringatan Kesehatan Pada Kemasan Rokok 2015. Artikel Ilmiah Fakultas Kesehatan Universitas Dian Nuswantoro. 2015. 
11. Onoruoiza, S.I., Musa, Umar ,B.D., danKunle. Using Health Beliefs Model as an Intervention to Non Compliance with Hypertension Information among Hypertension Patient. Journal Of Humanities and Social Science. 2015; Vol.5 No.9.

12. Smet. Psikologi Kesehatan. PT.Gramedia Widiasarana Indonesia, Jakarta. 1994.

13. Hayati, M., Sudiana, K.I., dan Kristiawati. Analisis Faktor Orang Tua Terhadap Status Gizi Balita Pendekatan Teori Health Belief Model. [Skripsi]. Universitas Airlangga . Surabaya. 2014.

14. Wardani, D.P.L., Sari, S.P., dan Nurhidayah, I. Hubungan Persepsi dengan Perilaku Ibu Membawa Balita ke Posyandu. Jurnal Kesehatan. 2013; Vol. 5: $1-10$.

15. Rosenstrock, I.M.., Stretcher, V.J., Becker, M.H. Social Learning Theory and The Health Belief Model Health Edu. 1988; Vol.15 No.2: 175-183.

16. Hammond, D., Thrasher, J., Reid, J,L. Perceived Effectiveness of Pictoral Warnings among Mexican Youth and Adults: a Population-Level Intervention with Potential to Reduce TobaccoRelated Inequities. Spinger Science Journal. 2012.

17. Trisnawan, P.D. Determinan Perilaku Pencarian Pengobatan Pada Mahasiswa Fakultas Kedokteran dan Ilmu Kesehatan UIN Syarif Hidayatullah Jakarta Angkatan Tahun 2013. [Skripsi]. Fakultas Psikologi Universitas Katolik. Semarang. 2013.

18. Setiyaningsih, R., Tamtomo, D., dan Suryani,N. Health Belief Model: Determinants of Hypertension Prevention Behavior in Adults at Community Health Center, Sukoharjo, Central Java. Journal of Health Promotion and Behaviour. 2016; Vol. 1 No.3: 165-175.

19. Sholihah M. Gambaran Peluang Perubahan Perilaku Perokok dengan Health Belief Model Pada Pasien Hipertensi di Puskesmas CiputatTangerang Selatan. Skripsi UIN Syarif Hidayatullah Jakarta. 2014.

20. Glanz, K., Barbara, K.R., dan K.Viswanath. Health Behavior and Health Education: Theory, Research, and
Practice Fourth Edition. USA. San Fransisco. 2008.

21. Binita, A.M., Istiarti, V.G.T., dan Widagdo, L. Hubungan Persepsi Merokok dengan Tipe Perilaku Merokok Pada Siswa SMK X Di Kota Semarang. Jurnal Kesehatan Masyarakat. 2016; Vol.4 No.5: 268-276.

22. Karren, K.J., Hafen, B.Q., dan Smith, N.L., dan Frandsen, K.J. Mind/Body Health: The Effect of Attitudes Emotions and Relationships. Benjamin Cummings, San Fransisco. 2002.

23. Darojah, S. Faktor Determinan Penghambat Berhenti Merokok Pada Kepala Keluarga Di Kecamatan Jaiyoso Kabupaten Karanganyar. Naskah Publikasi. 2014.

24. Sarafino, E.P. Health Psychology: Biopsichosocial Interaction. : John Wiley \& Sons, New York. 1990.

25. Imam, S.S. General Self-Eficacy Scale: Dimensionality, Internal Consistency, and Temporal Stability. Proceedings of the Redesigning Pedagody: Culture, Knowledge and Understading Conference, Singapore. 2007.

26. Paradita SA. Pengaruh Peringatan Kesehatan Bergambar Pada Kemasan Rokok terhadap Motivasi Perokok Untuk Berhenti Merokok. [Skripsi]. Universitas Diponegoro. Semarang. 2014.

27. Setyaningtyas D. Hubungan Perilaku Merokok dengan Risiko Insomnia pada Lansia di Dusun Daleman Gadingharjo Saden. Naskah Stikes Yogyakarta. 2014. 